\title{
CAPITALISING RURAL IDENTITY IN MĂRIȘELU VILLAGE, BISTRIȚA-NĂSĂUD COUNTY? FIRST STEP: EDUCATION FOR EQUESTRIAN AND HORSE-DRAWN CARRIAGE TOURISM
}

\author{
VASILE GRIGORE TURȘAN \\ Mărișelu Middle School, Bistrița-Năsăud County, Romania, e-mail: tursangrigore@yahoo.com
}

\section{MARIA ELIZA DULAMĂ}

Babeş-Bolyai University, Faculty of Psychology and Sciences of Education, Department of Exact Sciences Didactics, Cluj-Napoca, Romania, e-mail: dulama@upcmail.ro

\section{SORIN-ALIN KOSINSZKI}

Babeş-Bolyai University, Faculty of Psychology and Sciences of Education, Department of Exact Sciences Didactics, Cluj-Napoca, Romania, e-mail: kosinszki.sorin@gmail.com

\begin{abstract}
In the introduction of the paper, we presented theoretical aspects related to rural tourism, equestrian, and horse-drawn carriage tourism. Next, we presented the organisation of the research, and then we presented and analysed results. The research carried out in 2016 had two phases. In the first phase, questionnaires were administered to residents about equestrian and horse-drawn carriage tourism heritage of Mărişelu village and its capitalisation. In the second phase, a teaching experiment was held with 22 pupils in the primary grades from Mărişelu Middle School, Bistrița-Năsăud County, Romania. An initial test and a final one were applied, and in between, an experimental activity took place consisting of pupils' completion of a $25 \mathrm{~km}$ long route, during 12 hours through six villages of Mărişelu coomune, accompanied by teachers and parents in horse-drawn carriages.
\end{abstract}

Keywords: rural identity, cultural identity, rural image, rural landscape, rural tourism, cultural tourism 
VASILE GRIGORE TURȘAN, MARIA ELIZA DULAMĂ, SORIN-ALIN KOSINSZKI

\section{INTRODUCTION}

Rural tourism is generated by people's attraction to rural landscape, to the tranquility of the environment that enables relaxation, to traditions and customs, much better preserved than in the urban areas, to activities characteristic of this environment, in particular to those from farms and agricultural households. In Romania, the identity of the rural cultural landscape is given not only by traditional houses, but also by the cow herds, the sheep flocks, and by the animal-drawn carriages. Rural tourism vacations involve accommodation at the farm and spending time in the rural and agricultural space. A pleasant way to spend time in this environment is equestrian tourism.

In Romania, equestrian tourism has developed a lot in recent years. The National Committee for Equestrian Tourism (NCET) was set up, comprising equestrian centres, horse breeders, and dealing with the training of specialized guides. All equestrian centres offer leisure horse riding courses and tourist programmes that include completion of routes on horseback, or in horse-drawn carriages. Many guesthouses have equestrian facilities, where tourists can take horse-riding lessons (riding lessons in a manege). Horse riding is the study, art, and practice of horsemanship and horse riding. It involves the right postures and commands that a rider can properly master a horse to take him/her in the desired direction safely. Tourists can take horseback rides, in groups, on various routes (short or long, with varying degrees of difficulty, and different durations: short/medium/long, 1-2 hours/5-7 hours), or can participate at traditional carriage rides or on sleighs.

Equestrian tourism is more than just mounting a horse and its straight riding on a route. Tourists should know how to lead the horse to the chosen destination correctly and efficiently and how to return home safely together with the horse (http://www.desprecai.eu/generalitati/despreturismul-ecvestru/). To get out of the manege and enjoy a route, tourists/riders should have minimal knowledge about horses, their health and nutrition, about first aid measures, about equipping horses properly, about checking each time the equipment of horses to get out safely in nature, to know how to repair some elements of the harness, and how to get their bearings in the field (including with GPS devices) (http://www.desprecai.eu/generalitati/despre-turismul-ecvestru/). Riders should have good physical and mental condition to complete a route that lasts several hours. They should have appropriate equipment for horse riding (light boots or riding boots, raincoat, helmet, riding gloves, sunglasses, sunscreen, flashlight, GPS device, and a first aid kit) (http://www. desprecai.eu/generalitati/despre-turismul-ecvestru/).

In this paper, we analyse the perceptions of some residents from Mărişelu Commune (Bistrița-Năsăud Country) of equestrian and horsedrawn carriage tourism, perceptions that are related to their education and that are important for harnessing the touristic potential of the locality. We 


\section{CAPITALISING RURAL IDENTITY IN MĂRIȘELU VILLAGE...}

also analyse the knowledge and a few opinions on the topic of some primary school pupils from Mărişelu village (one of the seven villages of the homonymous commune), within a didactic formative experiment.

\section{THEORETICAL BACKGROUND}

Due to its natural and cultural strengths and weaknesses for developing tourism, the Romanian urban and rural areas were intensely documented. In Romania, recent research focused on the connection between tourism and development (Ciangă and Ilovan, 2004; Enea et al., 2015a, 2015b; Ilovan, 2013b; Ilovan and Maroşi, 2015), and on the economics of recreation, with recreation perceived as a commodity, contributing to creating jobs and national wealth (Sava, 2015).

In this context, diverse authors underlined the potential of leisure time tourism for revitalising emergent spaces in the urban area, more exactly in the metropolitan one (Pintilii et al., 2011), and especially for developing rural areas, based on their cultural diversity and natural assets (Cruceanu et al., 2015; Ilovan, 2010; Nistoreanu, 2007). For instance, Nistoreanu (2007) pointed out that rural areas experiment new ways of and new services for capitalising their touristic potential, while Chiran et al. (2016a, 2016b) focused on the development of rural tourism and agrotourism as efficient solutions for economic growth and boosting jobs in areas which were not included in mass tourism, but offer high levels of comfort and diverse entertainment and leisure activities.

Moreover, there is a trend in researching sustainable development in general (Boţan et al., 2005; Cocean and Ilovan, 2008; Ilovan and Sochircă, 2012), as well as sustainable development strategies for rural areas, where community participation is both ensured and documented (Ilovan and Mihalca, 2014, p. 27; lova et al., 2016). In addition, new systems of exploitation are created, targeting the conservation and protection of cultural and natural elements (Herman et al., 2016). Therefore, there is also research showing that tourism may be a misleading concept in the context of developing lagging behind areas "without an overall and longterm concept" (Nagy et al., 2016, p. 516).

Modern tourism includes a series of very popular activities, especially for the young, who look for entertaining and adventure, Petroman (2015) considering equestrian tourism a sub-type of rural tourism, adventure tourism, or of ecological tourism. Equestrian Tourism was approached from the perspective of its positive and negative impact on the environment and on development (Petroman, 2015).

In addition, Samfira and Petroman (2011) researched the relationship between agritainment, community development, and education, underlining the potential of turning animal farms into educational agrotouristic farms. They concluded that these farms had a significant role, being able, through 
their activities, "to educate the new generation through the relation with animals' life and care, eating natural food and being creative in the nature" and "to develop and strengthen certain traits in children's personality", also having "advantages for parents, teachers and the local community" (Samfira and Petroman, 2011, p. 516).

In this research, we also used the theoretical perspective and general framework created by recent research on development and tourism in Bistriţa-Năsăud County (Ilovan and Dulamă, 2006; Cocean et al., 2011; Cocean and Ilovan, 2009; Ilovan, 2005, 2006, 2007, 2008, 2009, 2010, 2012, 2013a, 2013c), where our case study is located.

\section{MATERIAL AND METHOD}

Research design. The research carried out during February-May 2016 had two phases. In the first phase, we administered questionnaires to some residents of Mărişelu village with questions only about one of the villages of this commune: Mărişelu village. The questionnaire on equestrian and horsedrawn carriage tourism heritage from Mărişelu village and its capitalisation was administered to 10 local community representatives. The questionnaire consisted of 7 items: a dual choice item, four multiple choice items, and 2 items with a sliding scale from 5 to 1 .

A questionnaire with similar items was administered to 15 parents and teachers. The questionnaire consisted of 9 items: 2 dual choice items, 5 multiple choice items, and 2 items with a sliding scale from 5 to 1 . A questionnaire on the use of horses and horse-drawn carriages was administered to 50 owners of horses and carriages in Mărişelu village. The questionnaire consisted of 9 items: 5 multiple choice items, 2 dual choice items, and 2 items with open questions.

In the second phase of the research, we organised a didactic experiment at Mărişelu Middle school, in Mărişelu village, Bistrița-Năsăud County. We tested the hypothesis: if pupils participate in an equestrian and horse-drawn carriage tourism activity, they gain knowledge and form attitudes and skills related to this topic. The research variables were the following: the independent variable - the learning activities in which the pupils were involved; the dependent variable - the pupils' knowledge, attitudes, and skills about equestrian and horse-drawn carriage tourism.

At the beginning of the experiment, we administered an initial test (pretest) to assess pupils' knowledge about equestrian and horse-drawn carriage tourism. The test comprised 5 multiple choice items, 2 dual choice items, and 3 open questions. The experimental activity consisted of pupils' completion, accompanied by teacher and parents, in horse-drawn carriages, of a $25 \mathrm{~km}$ long route, in 12 hours, through six of the villages of Mărişelu commune. The only unvisited village was Măgurele. Along the route and during stops in various locations, they conducted several learning and 


\section{CAPITALISING RURAL IDENTITY IN MĂRIȘELU VILLAGE...}

leisure activities (Table 1). After completing this activity, at school, we applied a final test (posttest), with items similar to the initial test, correlated with the contents of the learning activities pupils' carried out along the tourist route.

Table 1. The tourist route completed by pupils, parents and teacher

\begin{tabular}{|c|c|c|}
\hline Villages & Routes & Activities \\
\hline Mărişelu & Mărişelu - Domneşti & $\begin{array}{l}\text { - Visiting the Orthodox Church } \\
\text { - Visiting the Parish Museum inside the } \\
\text { church } \\
\text { - Visiting two traditional houses } \\
\text { - Studying Lake Mărişelu } \\
\text { - Role-play games (Tour Guide) - Lake } \\
\text { Mărişelu } \\
\text { - At the cross - competition about } \\
\text { horses, carriages, and equestrian } \\
\text { tourism }\end{array}$ \\
\hline Domneşti & $\begin{array}{l}\text { Domneşti - Valea } \\
\text { Măgurii - Pe poieniţă - } \\
\text { Ciuncăr- Bârla }\end{array}$ & $\begin{array}{l}\text { - Visiting the Orthodox Church } \\
\text { - Studying the Ravine with Dolls } \\
\text { Reserve } \\
\text { - Picnic - lunch at Făget } \\
\text { - Studying the oak forest }\end{array}$ \\
\hline Bârla & Bârla - Sântioana & - Visiting the Orthodox Church \\
\hline Sântioana & $\begin{array}{l}\text { Sântioana - Podirei - } \\
\text { Dealul Tâlharilor }\end{array}$ & $\begin{array}{l}\text { - Visiting the Orthodox Church in } \\
\text { Sântioana }\end{array}$ \\
\hline Jeica & Jeica - Ciungi - Neţeni & $\begin{array}{l}\text { - Visiting the sheepfold } \\
\text { - Preparing polenta with sheep milk } \\
\text { cheese }\end{array}$ \\
\hline Neţeni & $\begin{array}{l}\text { Neţeni - Făget - } \\
\text { Bobeica - Mărişelu }\end{array}$ & $\begin{array}{l}\text { - Bobeica - Relaxing at the Salt Baths } \\
\text { in Sărăţel; } \\
\text { - Bobeica - Studying the Salt Mountain } \\
\text { in Sărăţel } \\
\text { - Visiting a traditional house } \\
\text { - Visiting the sheepfold } \\
\text { - Camp fire }\end{array}$ \\
\hline
\end{tabular}

Participants. In this research, were involved 10 representatives of the local community, 15 parents and teachers, 50 owners of horses and carriages from Mărişelu village, 22 pupils ( 11 boys and 11 girls) in the primary grades at Mărişelu Middle School and the teacher for the primary school, the first 
author of the present paper, whom pupils perceived as a teacher, not as a researcher.

Research material. In this research, the answers to the questionnaires administered to the adults and the test administered to the pupils was the research material. During the activity of equestrian and horse-drawn carriage tourism, we noticed the pupils' attitudes and skills related to horses, to the participants, and to the environment.

Research methods. For collecting data, we used the survey method based on questionnaires; the test as a tool for collecting data in the didactic experiment, alongside with systematic observation. For processing and representing data, we used Excel software.

\section{RESULTS AND DISCUSSION}

1. Analysing the answers to the questions from the questionnaires adminstered to the adults

To the question "Do you know what equestrian and horse-drawn carriage tourism is?", $80 \%$ of the local community representatives, $80 \%$ of the parents and teachers, $76 \%$ of the owners of horses and carriages from the Mărişelu village answered affirmatively. Although a large number of respondents have the perception that they know what equestrian and horse-drawn carriage tourism is, we assume that they do not have all the necessary knowledge to understand deeply this type of tourism and its organising at a professional level, which indicates the need to realise information campaigns or training courses in this area.

Then, to the question "How many horses live in the citizens" households in Mărişelu village?", $70 \%$ of local community representatives answered that there were between 50 and 100 horses and three interviewed people said there were between 100 and 200 horses. $66 \%$ of the parents and teachers said there were many horses and $34 \%$ of the surveyed people said that there were very many horses. In Mărişelu village, there are 66 horses, so the local community representatives have a good perception of their number.

In addition, to the question "How many horse-drawn carriages are in the citizens' households from Mărişelu village?", 60\% of the local community representatives said there were between 50 and 100 carriages and $40 \%$ of the surveyed people said there were between 10 and 50 carriages. We underline that most of the surveyed people did not perceive correctly this number, because in Mărişelu village there are 38 carriages.

Moreover, to the question "How important do you think the tourist sights in our area are?", $80 \%$ of the local community representatives said that they were very important and $20 \%$ said they were important. The percentage is different for parents and teachers. Thus, $53 \%$ of them answered that the sights were very important and $47 \%$ of them that they were important. Even if teachers had a more realistic perception on the 


\section{CAPITALISING RURAL IDENTITY IN MĂRIȘELU VILLAGE...}

value of local sights, the fact that such a high percentage of the local community representatives believed that the sights were very important created the potential that they wanted to protect and capitalise them.

The answer to the question "How important is the capitalisation of equestrian and horse-drawn carriage tourism at the local community level?" supports our previous statement: $70 \%$ of the local community representatives answered that capitalising equestrian and horse-drawn carriage tourism was very important to the local community, $20 \%$ of respondents answered that it was important, while $10 \%$ said they did not know. This importance should be assessed in relation to other resources from the local horizon that could be exploited.

The local community representatives, the parents and teachers were asked to rank on a Likert-type value scale from 1 to 5 , the benefits of equestrian and horse-drawn carriage tourism to the local community. From the local community representatives, we had the following scores: implementation of new jobs - score 40; increasing the financial budget of public administrations - score 40; encouraging young people to spend their lives in their native village - score 29; highlighting tourist sights - score 27; forming pupils' positive attitude towards their own community - score 14. From parents and teachers, we had the following results: implementation of new jobs - score 57; increasing the financial budget of public administrations - score 52; encouraging young people to spend their lives in their native village - score 47; forming pupils' positive attitude towards their own community - score 38; highlighting tourist sights - score 31 . The order is the same as that established by local community representatives, except the last two positions.

The parents and the teachers answered some more questions. When asked "Would you like to practise equestrian tourism in a well organized tourist facility?", $73 \%$ of the respondents answered that they would like very much and $27 \%$ of them answered that they would like it a lot. When asked "Do you want a facility for equestrian tourism to be implemented at European standards in your village?", all the respondents answered affirmatively. When asked "How important is the involvement of primary school pupils in the activities of equestrian and horse-drawn carriage tourism?", 93\% of respondents answered that it was very important, and $7 \%$ (one interviewee) responded that it was important.

The 50 owners of horses and carriages from Mărişelu village were questioned on issues of capitalising the potential of equestrian and horsedrawn carriage tourism at present. When asked "Would you like to practise this form of tourism?", $80 \%$ of the respondents answered positively.

When asked "How much would you charge a tourist or a group of tourists for a ride?" the owners of horses and carriages from the Mărişelu locality opted for different prices: $30 \%-100-150$ lei; $24 \%-50$ lei; $20 \%$ free; $8 \%-10-50$ lei; $6 \%$ - 200. $12 \%$ of the surveyed said they would charge an amount that depends on certain conditions: length of the route, comfortableness and safety etc. 


\section{VASILE GRIGORE TURȘAN, MARIA ELIZA DULAMĂ, SORIN-ALIN KOSINSZKI}

To the question "Do you think that such an activity would be beneficial for you? And for the community?", 34 owners of horses and carriages from Mărişelu village replied affirmatively in both cases; one respondent answered negatively in both cases; 7 respondents answered affirmatively in the first case and negatively in the second; 8 respondents answered $N o$ in the first case, and Yes in the second one.

\section{Analysing pupils' answers at the tests concerning their knowledge about equestrian and horse-drawn carriage tourism}

To the initial test, to the question "What animals from the households of Mărişelu village pull the carriages and sleds?", all pupils answered correctly (the horses). To the initial test, concerning horse breeds, 2 pupils $(11 \%)$ mentioned three races, 7 pupils (31\%) mentioned 2 races, 7 pupils $(31 \%)$ mentioned one race, 6 students $(27 \%)$ wrote wrong breed names or did not answer the question, while at the final test, each pupil mentioned at least three horse breeds.

Regarding the horse care activities, at the initial test, $15 \%$ of the pupils listed three activities, $41 \%$ listed two activities, $22 \%$ mentioned one activity and $22 \%$ none or provided inadequate answers. Solving this item was influenced by the fact that pupils' parents were or were not horse owners. After the activities in the horse-drawn carriages (Figure 1), all pupils mentioned at least three activities of horse caring.

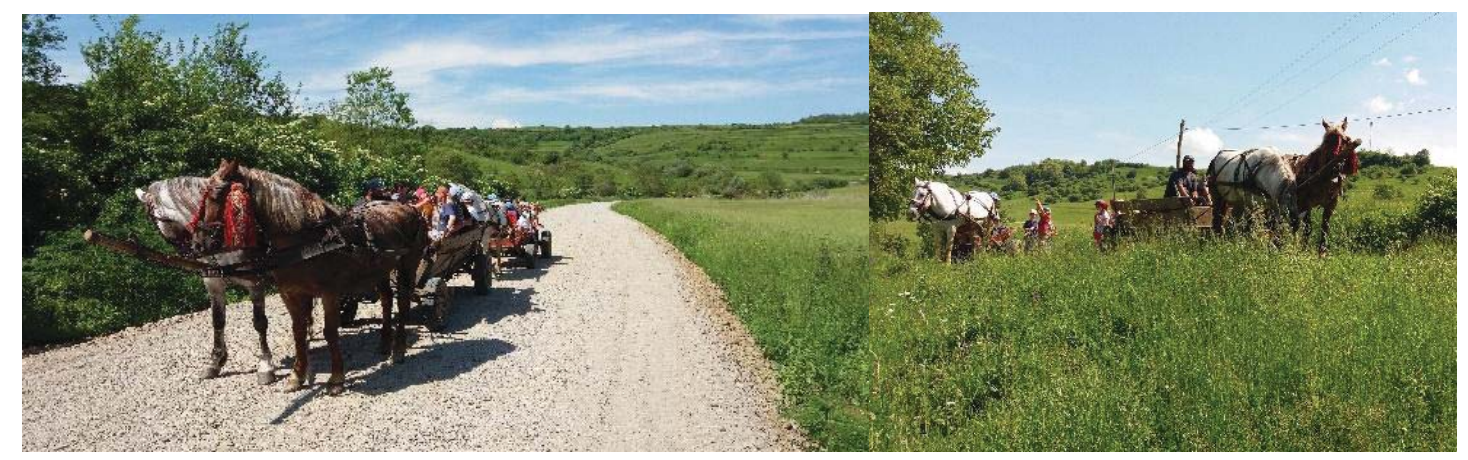

Fig. 1. Pupils visiting their commune in horse-drawn carriages

All pupils claimed they saw in movies that horses were used for riding, racing, circus, pulling carriages, and plowing the field. Marking all the answers indicates that pupils are aware of the multitude of activities where people use horses. Unlike in the movies, in the households from Mărişelu village all pupils believe that the main use for horses is pulling carriages, plows and other agricultural equipment, not for carrying tourists around, racing, or for circus. All the pupils know the name of carriage and cart, these being the horse-drawn carriages, characteristic of the rural landscape of Mărişelu village and of other villages in Romania. The carriages and carts have disappeared from the Romanian landscape. We point out that the current carriages are different in design from those of the last few decades, these carriages being named "ștraif/ștraifuri" in Mărişelu commune. The term is derived from the German regionalism (Straf - wagen) and it is a 


\section{CAPITALISING RURAL IDENTITY IN MĂRIȘELU VILLAGE...}

"wagon with a box, like a trailer with rubber wheels; usually pulled by horses. It replaced, in the second half of the $20^{\text {th }}$ century, the carts with wooden wheels, pulled by cows or by water buffaloes" (straf, dexonline.ro). Nowadays, in Mărişelu village there is only one cart with wooden wheels, which is used neither for transport, nor as an object to be admired, but it is hidden in a courtyard.

All the pupils listed, in the initial test, three beautiful places in Mărişelu village and the surrounding areas (in the commune), that we should visit by horse riding or in a horse-drawn carriage. First place is held by the Salt Baths in Sărăţel, second place by Lake Mărişelu, third place by the Parish Museum inside Mărişelu church, and fourth place by the Orthodox church in Mărişelu, followed by the Ravine with Dolls Reserve in Domnești. We underline that these pupils were attracted, firstly, by the entertainment locations of the commune and less by its cultural sights. We emphasize that they predominantly listed sights from their village and very few from the other villages of their commune. At the final test, these pupils listed far more tourist sights from their village than at the initial test. Their list included the Orthodox churches from the villages of Domnești, Barla, Sântioana, traditional houses, and sheepfolds.

The pupils also received two more items in order to find out their views. Thus, $60 \%$ of them claimed that if they were tourists they would like to visit Mărişelu village, in a horse-drawn carriage, $20 \%$ would go on foot, $10 \%$ on horseback, and $10 \%$ in a cart. We point out that pupils opted for a more convenient and spectacular means of transport - the carriage. On the second place, mainly boys preferred to visit the village riding on horseback. Regarding horse caring, only $10 \%$ of these pupils claimed they knew how to care for horses, $5 \%$ of the pupils said that they liked to care for horses, but the percentage of those who said that they would love to care for horses was much higher: $25 \%$. So, on the one hand, the pupils are of young age and have not taken activities of horse caring and, on the other hand, they have never been in situations where to care for horses, not having such animals in the household.

\section{Analysing the activities during the completion of the tourism route}

According to the means of transport, the activity fits into the category of equestrian carriage tourism. Because pupils have acquired knowledge about horses, and some have formed riding attitudes and skills, including driving the horse-drawn carriage, the activity fits into the equestrian tourism category. The chosen tourist route targeted visits to cultural tourist sights (e.g. religious tourist sights - the Orthodox churches in Mărişelu, Domneşti, Bârla, and in Sântioana; museum tourist sights - the Parish Museum inside the church of Mărişelu; two traditional houses in Mărişelu; a traditional house in Neţeni; the sheepfolds in Jeica and in Neţeni) and the unfolding of characteristic activities for the rural area (preparing polenta with sheep milk cheese in J eica - Figure 2).

They included sights and activities characteristic of scientific tourism: visiting the Ravine with Dolls Nature Reserve in Domnești; the Salt 
Mountain from Sărăţel to Bobeica; studying Lake Mărişelu; studying the Oak Forest in Domnești). Two activities with educational purpose were also organised: Role-play games (Tour Guide) - Lake Mărişelu; competition about horses, carriages, equestrian tourism - at the Cross (Mărişelu). During the carriage ride, the pupils learned to drive it. The pupils also participated at leisure activities: picnic - lunch at Faget (in Neţeni); relaxing at the Salt Baths in Sărăţel; Campfire (in Neţeni).

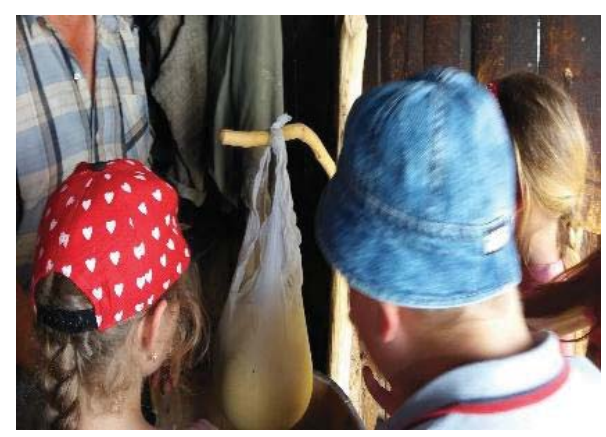

Fig. 2. Pupils at the sheepfold, looking at cheese held in a traditional case

During the activities organised while completing the route and at the resting locations, through the final test, we found that the pupils gained more knowledge about equestrian and horse-drawn carriage tourism, about types of horse races (i.e. for traction, riding, and exhibition), about harnessing and driving the horse-drawn carriages, about training and riding horses, about tourist sights and places of recreation in their village and commune.

More importantly, this activity had a strong impact on at least some of these pupils. For instance, after the field trip, one of them drew voluntarily a horse and a carriage, meaning that that pupil was fond of or has learnt to be fond of horses (Figure 3).

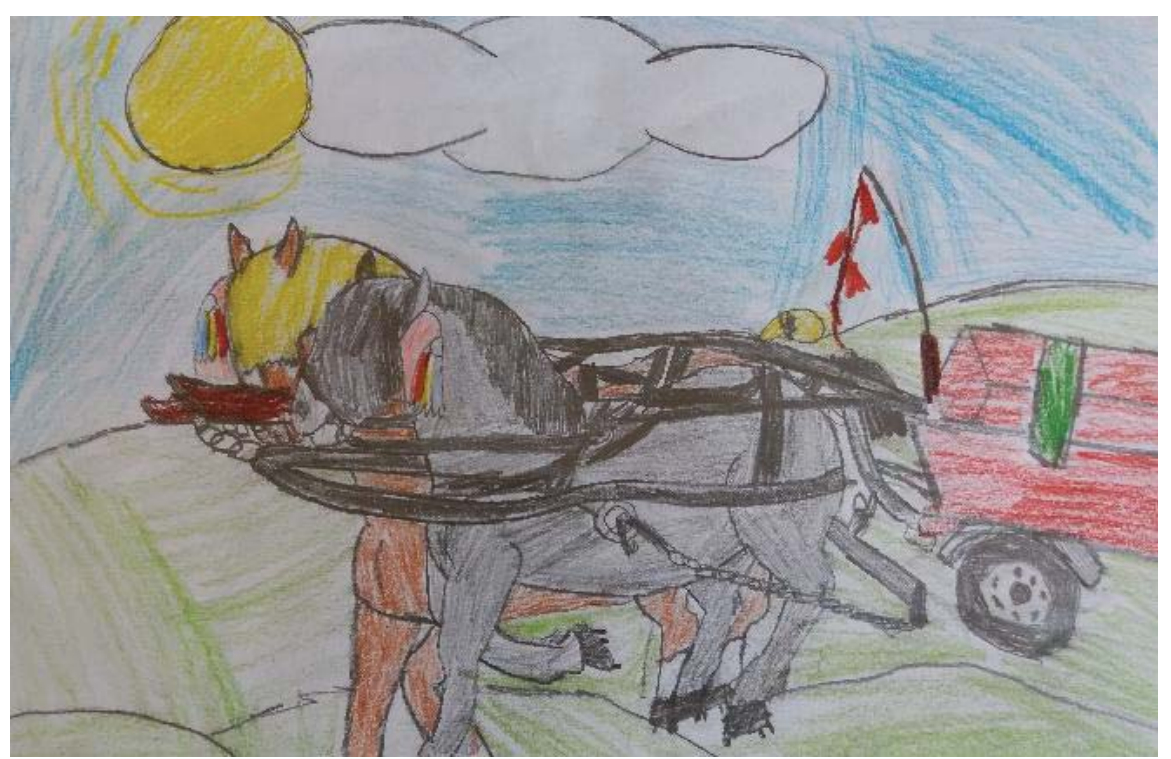

Fig. 3. A pupil's drawing: Horses and carriage 
CAPITALISING RURAL IDENTITY IN MĂRIȘELU VILLAGE...

\section{CONCLUSIONS}

Regarding the perceptions of some residents from Mărişelu commune (Bistrița-Năsăud County) on equestrian and horse-drawn carriage tourism, perceptions that are related to their level of education and that are important for capitalising the tourism potential of this commune and of the homonymous village, we drew several conclusions. The local community representatives and other residents perceived relatively more accurately the number of horses than that of the horse-drawn carriages in Mărişelu village. A high percentage of residents believe the tourist sights in the area are very important, which creates the potential that they will want to protect and capitalise them. Most of them believe that the capitalising equestrian and horse-drawn carriage tourism is very important to the local community. The 50 owners of horses and horse-drawn carriages in Mărişelu village are interested in practising this form of tourism and consider it beneficial for them and for the community, too.

Regarding primary school pupils' knowledge, at the begining of the experiment we learnt they had more knowledge about horse feeding and about the activities in which they might have been involved, and they had less knowledge about breeds of horses and their care. As tourists, most of these pupils claimed that they would like to visit Mărişelu commune, in a horse-drawn carriage, and the most attractive places for them were the Salt Baths in Sărăţel and Lake Mărişelu. They showed less curiosity about their scientific nature reserves or cultural sights. The amount of knowledge and practical skills was much higher after going on a touristic route through the village, in horse-drawn carriages, which proves the value of experiential learning activities.

\section{References}

Boţan, C. N., Ilovan, O.-R., \& Pop, A.-M. (2005). The Geographical Region and the Desiderata of Sustainable Development. Romanian Review of Regional Studies, 1, 83-90.

Chiran, A., Gîndu, E., Jităreanu, A.F., Vîntu, C.R., \& Ciornei, L. (2016a). Efficiency Opportunities for the Agrotouristic Activities in Bucovina (Case Study in Vama, Suceava County). Lucrări Ştiinţifice, 18(1), 235-244.

Chiran, A., Jităreanu, A.F., Gîndu, E., \& Ciornei, L. (2016b). Development of Rural Tourism and Agrotourism in Some European Countries. Lucrări Ştiinţifice, $18(1), 225-234$.

Ciangă, N., \& Ilovan, O.-R. (2004). Structural Changes within the Romanian Tourism during the Transition Period. In Buletinul Societăţii de Geografie din România, New series, 10(80), pp. 57-62, Special Issue Dedicated to the Congress of the International Geographical Union "One Earth - Many Worlds", Glasgow, 15-20 August 2004. Bucureşti: CD Press. 


\section{VASILE GRIGORE TURȘAN, MARIA ELIZA DULAMĂ, SORIN-ALIN KOSINSZKI}

Cocean, P., \& Ilovan, O.-R. (2008). Elemente ale managementului dezvoltării durabile. Geographia Napocensis, 2-(2), 5-17.

Cocean, P., \& Ilovan, O.-R. (2009). SAPARD Programme and Its Implementation in Tourism Development in Bistriţa-Năsăud County, Romania, Revija Za Geografijo-Journal for Geography, Special Issue for the $17^{\text {th }}$ Annual Colloquium of the IGU Commission on the Sustainability of Rural Systems2009, Department of Geography, Faculty of Arts, University of Maribor, Maribor, Slovenia, 4-(1), 163-174.

Cocean, P., Boţan, C.N., \& Ilovan, O.-R. (2011). Judeţul Bistriţa-Năsăud. Bucureşti: Editura Academiei Române.

Cruceanu, A. D., Muntele, I., \& Cazacu, M. D. (2015). Ways of Valorization of the Touristic Potential in Tara Dornelor. SEA - Practical Application of Science, III, 1(7), 193-202.

Enea, C., Enea, C., \& Sanda, G.G. (2015a). Strengths and Weaknesses of Tourism in Northern Oltenia Potential Compared with European Alpine Countries. Annals of the "Constantin Brâncuşi" University of Târgu Jiu, Economy Series; 1(Special number - Information society and sustainable development), 281-286.

Enea, C., Enea, C., \& Sanda, G.G. (2015b). Travel Planning Proposals Ski Area in North Oltenia to Increase Visibility at National Level. Annals of the "Constantin Brâncuşi" University of Târgu Jiu, Economy Series, Special Issue - Information society and sustainable development, 50-55.

Herman, G. V., Ilieș, D. C., Baias, Ș., Măduța, M. F., Ilieș, A., Wendt, J. A., \& Josan, I. (2016). The Tourist Map, Scientific Tool That Supports the Exploration of Protected Areas, Bihor County, Romania. GeoSport for Society, 4(1), 24-32.

Ilovan, O.-R. (2005). Coordonatele geodemografice ale unui sistem rural progresiv, în perioada 1990-2002. Studiu de caz: comuna Rebra, judeţul BistriţaNăsăud. Studia UBB, Geographia, 1, 87-92.

Ilovan, O.-R. (2006). Năsăudului Land in "After 1989" Romania - Between Effervescence and Decline. The Geographical Aspects of the Transformation Process in Central and East-Central Europe, Michalski, T. edition, GdynisPeplin, 161-170.

Ilovan, O.-R. (2007). Feldru Commune in Bistriţa-Năsăud County. Rural Development Model. In V. Surd, \& V. Zotic (Eds.), Rural Space and Local Development (pp. 286-297). Cluj-Napoca: Presa Universitară Clujeană.

Ilovan, O.-R. (2008). Identitatea regională a Jării Năsăudului. Studia UBB, Geographia, 53-(2), 139-154.

Ilovan, O.-R. (2009). Tara Năsăudului. Studiu de Geografie Regională. Cluj-Napoca: Presa Universitară Clujeană.

Ilovan, O.-R. (2010). Caracteristicile patrimoniului construit şi zestrea "ţărilor" din bazinul românesc al Tisei. In Materialele conferinţei ştiinţifice internaţionale "Învătământul universitar din Republica Moldova la 80 de ani", 28-29 September 2010, Chişinău. Probleme actuale ale Ştiinţelor biologice, chimice şi geografice (pp. 141-148). Chişinău: Universitatea de Stat din Tiraspol.

Ilovan, O.-R. (2010). Features of the Built Patrimony and the Heritage of the "Lands" in the Romanian Tizsa Basin. Romanian Review of Regional Studies. Journal of the Centre for Regional Geography, 6(2), 41-46. 


\section{CAPITALISING RURAL IDENTITY IN MĂRIȘELU VILLAGE...}

Ilovan, O.-R. (2012). Relevanţa turismului regiunii năsăudene în cadrul judeţului Bistriţa-Năsăud, România. In Volumul 31 Lucrări Știinţifice: Economie (pp. 372-382). Chișinău: Universitatea Agrară de Stat din Republica Moldova.

Ilovan, O.-R. (2013a). Capitolul I: Cadrul natural şi administrativ-teritorial. In V. Lechinţan, A. Onofreiu, \& M. Prahase (Eds.), Fabricat în Runcu Salvei. Aspecte monografice (pp. 15-82). Cluj-Napoca: Editura Eikon.

Ilovan, O.-R. (2013b). Integrating the "Lands" of Romania in the Experience Economy. Romanian Review of Regional Studies, 9(1), 91-98.

Ilovan, O.-R. (2013c). Paradigma economiei experienţei - cadru pentru dezvoltare regională în "ţările" din România. In C. Vert (Ed.), Volumul conferinţei naţionale a Societăţii de Geografie din România, Timişoara, 24-26 May 2013, ediţia a X-a, cu tema Geografia - Ştiinţă a întregului teritorial (pp. 840-847). Timișoara: Editura EUROBIT.

Ilovan, O.-R., \& Dulamă, M.E. (2006). Exploatarea potentialului turistic al Muntilor Rodnei. In M. Mazilu, L. Popescu, \& D. Dănciulescu (Eds.), La un pas de integrare: oportunităţi şi ameninţări, I (pp. 63-68). Craiova: Editura Universitaria.

llovan, O.-R., \& Maroşi, Z. (2015). Leadership and Regeneration of the Transylvanian Villages in the Region of Rupea. Tiziana Banini, Fabio Police (ed.) Semestrale di Studi e Ricerche di Geografia, Rural Development Policy and Local Identities in the European Union, 27(1), 63-70.

Ilovan, O.-R., \& Mihalca, I.-A. (2014). Utilizarea metodelor calitative de cercetare în Geografia Regională. Geographia Napocensis, 8(1), 19-36.

Ilovan, O.-R., \& Sochircă, E. (2012). Coordonatele dezvoltării regionale durabile în economia cunoaşterii. In vol. Conferinţei Ştiintifice Internaţionale Competitivitatea şi Inovarea în Economia Cunoaşterii, 28-29 September 2012, Chişinău, Republica Moldova (pp. 137-140). Chişinău: Editura ASEM.

Iova, A. R., Creţu, D., \& Oltenacu, N. (2016). Sustainable Development Strategy of Rural Area by the Community Participation - Case Study. Scientific Papers Series Management, Economic Engineering in Agriculture and Rural Development, 16(1), 227-232.

Nagy, H., Nagy, A., \& Káposzta, J. (2016). The Role of Tourism Types in the Context of Rural Development in Hungary. 516-527, Retrieved 10 June 2016, from http://spu.fem.uniag.sk/mvd2016/proceedings/en/articles/s7/nagy_nagy_ka poszta.pdf

Nistoreanu, P. (2007). Aprecieri Asupra Fenomenului Turistic Rural [Appreciations on the Rural Touristic Phenomenon]. Revista de turism, 3, 16-23.

Petroman, I. (2015). Impact of Equestrian Tourism on the Environment. Scientific Papers: Animal Science and Biotechnologies, 48(1), 333-337.

Pintilii, R.D., Merciu, F.C., Cercleux, A.L., \& Drăghici, C.C. (2011). Sports and Leisure Time Tourism - A Way of Revitalising Emergent Spaces from the Metropolitan Area of Bucharest. Analele Universităţii din Oradea - Seria Geografie, XXI(2), 323-332.

Retrieved 26 May 2016, from http://www.desprecai.eu/generalitati/despreturismul-ecvestru/ 


\section{VASILE GRIGORE TURȘAN, MARIA ELIZA DULAMĂ, SORIN-ALIN KOSINSZKI}

Samfira, M., \& Petroman, I. (2011). New Opportunities of Valorising Animal Produce: Turning Animal Farms into Educational Agrotouristic Farms. Scientific Papers: Animal Science and Biotechnologies, 44(2), 516-519.

Sava, A.M. (2015). Brief Depiction of the Local Recreation Labour Market. A Comparative Approach between France and Romania. Annals of the "Constantin Brâncuşi" University of Târgu Jiu, Economy Series, 2, 211-221.

Ştraif, Retrieved 26 May 2016, from dexonline.ro 